\title{
関東大震災後の銀座における空間構成の継承と変容に関する研究 SUCCESSION AND CHANGE OF SPACE CONSTITUTE ON GINZA IN THE LATTER SHOWA PERIOD AFTER GREAT KANTO EARTHQUAKE
}

岡本哲志*

Satoshi OKAMOTO

\begin{abstract}
The earthquake that occurred at about noon on September 1 in the twelfth year of the Taisho Period(1923) was a major earthquake. The aim of this study is to make a searche for successive and changeful space constitutes after the damage. First, it clears succession of space constitutes in the Eary Showa Period to compare with the Latter Meji Period. Then it draws changes of space constitutes in the Eary Showa Period from the view point of construction of modern architectures after the Great Kanto Earthquake.

As a result, we can characterize space constitutes on Ginza in the Eary Showa Period.
\end{abstract}

Keywords : Great Kanto Earthquake, Succession, Modern Architecture, Cbange, Space Constitute 関東大震災、継承、近代建築、変容、空間棈成

\section{1.はじめに}

銀座は、大正12年9月1日に起きた関東大霞災により、棟瓦建築で つくられた街並みが構造壁だけを残して焼失している。その跡には、 近代建築が建ち、モダン都市に変貌した。この都市空間の破壊と再 生で、銀座はその構造を大きく変えたかに見える。

本研究では、明治後期と昭和初期の 2 つの時代の土地と建物と路 地との関倸の違いを比較の視点で捉え、昭和初期における敷地の空 間構成の継承之変容のあり方を明らかにするものである（注 3 ）。 特に、空間構成の変容に関しては、関東大震災後に出現した大規模 な近代建築に着目している。

本研究は以下の流れで論を展開する。第 1 に、前時代がつくりだ した空間構成を継承した敷地がどのように存在し、分布特性を示し ているのかについて分析する。その上で、第 2 点目では、関東大震 災以降に現れた大規模な近代建築が立地する条件を導きだすために、 前時代の敖地之建物の関係の変化から 7 つのパターンに分類し、そ の特色を示す。第 3 点目には、これらのビルの立地が銀座の都市構 造の特色を示す重要な要素の一つ、路地構成をどのように変化させ たのかについて考察を加えている。第 4点目は、この第 1 、第 2 、 第 3 で検討した内容を踏まえ、まとめとして昭和初期の空間構成の 特色を総括する。

\section{2. 前時代の空間權成を継承した教地とその土地所有者の特性}

銀座は、帝都復興の一瑻として、部分的に道路の㹡幅・付け替え、 土地区画整理が行われた。それによる街区形状の変化した場所が幾 つか確認できる（注 4)。だがそれらを除けば、日本橋や神田など の下町と異なり、銀座全体では街区形状に大きな变化が見られなか つた（図 1)。このような状海を踏まえ、具体的な例を示しながら、 まず明治後期の空間構成が継承された敷地について検討する。これ らは、敷地規模の特性から、2つのパターンに分けて考えることが できる（注 5)。一つは100 坪前後の規模をもつ「町屋敷型」（注 6)の教地、いま一つは大家と店子の関係が生き続けている300坪を 越える大規模な敷地である。

\section{（1）町屋數型の空間構成を継㴍した敷地}

最初にあげる 100 坪前後で、間口が狭く奥行が深い典型的な「町 屋敷型」の敷地には、関東大震災を経験した以降も、明治後期に見 られた一つの敨地に複数の建物を建てるケースが大半を占めていた （注 7）。敷地内の空間構成は、明治期の棟瓦街時代と同様に通り 沿いに商店が建てられ、その奥に住居用の建物、さらに裹通り側に も商店や住宅が並ぶ。これらの敖地は、銀座通り沿いや横丁沿いに その多くが分布している。以下 $2 つ の$ 例を示しながら、具体的に見 ていくことにしたい。

一つ目の例は、銀座2丁目にある銀座通り治いの早川弘次が所有 する數地である（図2）。これは間口が 6 間弱の幅で、奥行のある 標淮的な町屋敫型の敖地である。震災後、この數地には銀座通り側 
図1 明治後期と昭和初期の敷地割り比較

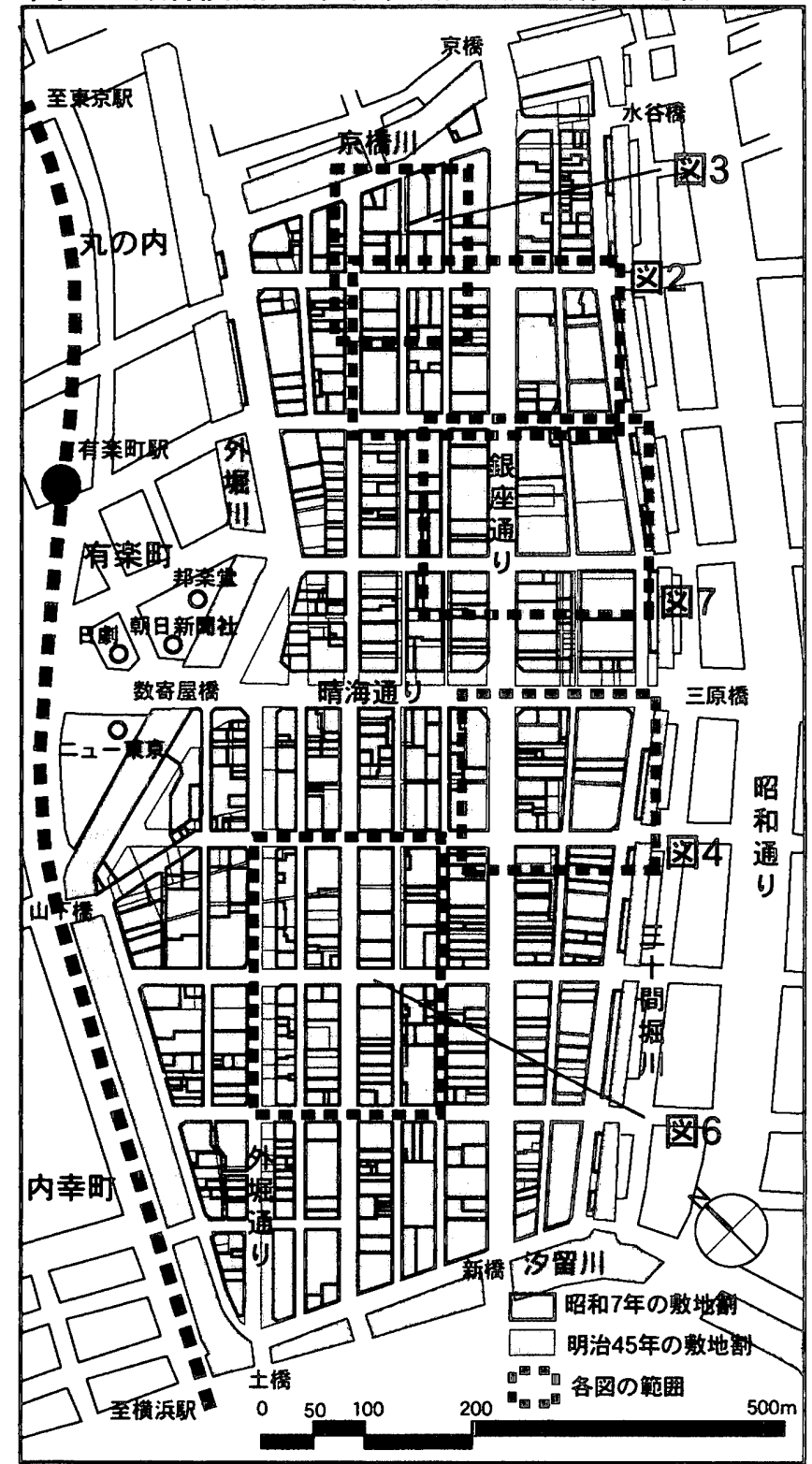

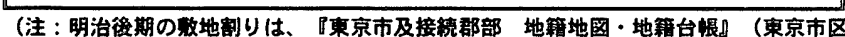

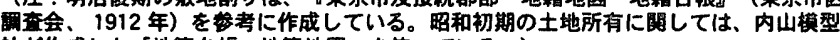
社が作成した地籍台棖、地籍地图」を位っている。)

に間口 3 間程度の店舗が 2 軒並び、その反対側の裹通りにも店舗が 建つ。敷地の内側の路地に面した所には住宅が建てられる。これは、 明治後期とほぼ同じ建物配置である。この地主である彼の先代・早 川喜兵衛は、明治期ここで酒商を営んでいたが、昭和初期には日暮 里に所在地を移し、不在地主となっている。このような䓪地形態の 場合、建物が新しく建て替わり、地主のあり方が変化しても、明治 後期に見られた敷地と建物と路地がつくりだす基本な空間構成のパ ターンは継承している。

いま一つの例としては、銀座 $1 丁$ 目の横丁（銀座柳通り）に沿つ た米商・土志田與助の敷地がある（図 3 ）。彼の店は煉瓦街建設以 前から同地で米商を営む商人地主であった。この影地は先の早川弘 次の敷地とほぼ同じ規模と形態である。ただ、ここは横丁に面して いることから、教地の裹側が通りではなく、路地となっている。そ のために、路地側には店舗が張り付くことなく、長屋などの居住用 の建物が占める。彼は、震災後も同地で米商を続けており、早川弘
図2 土地と建物の関係比較図1（銀座2丁目）
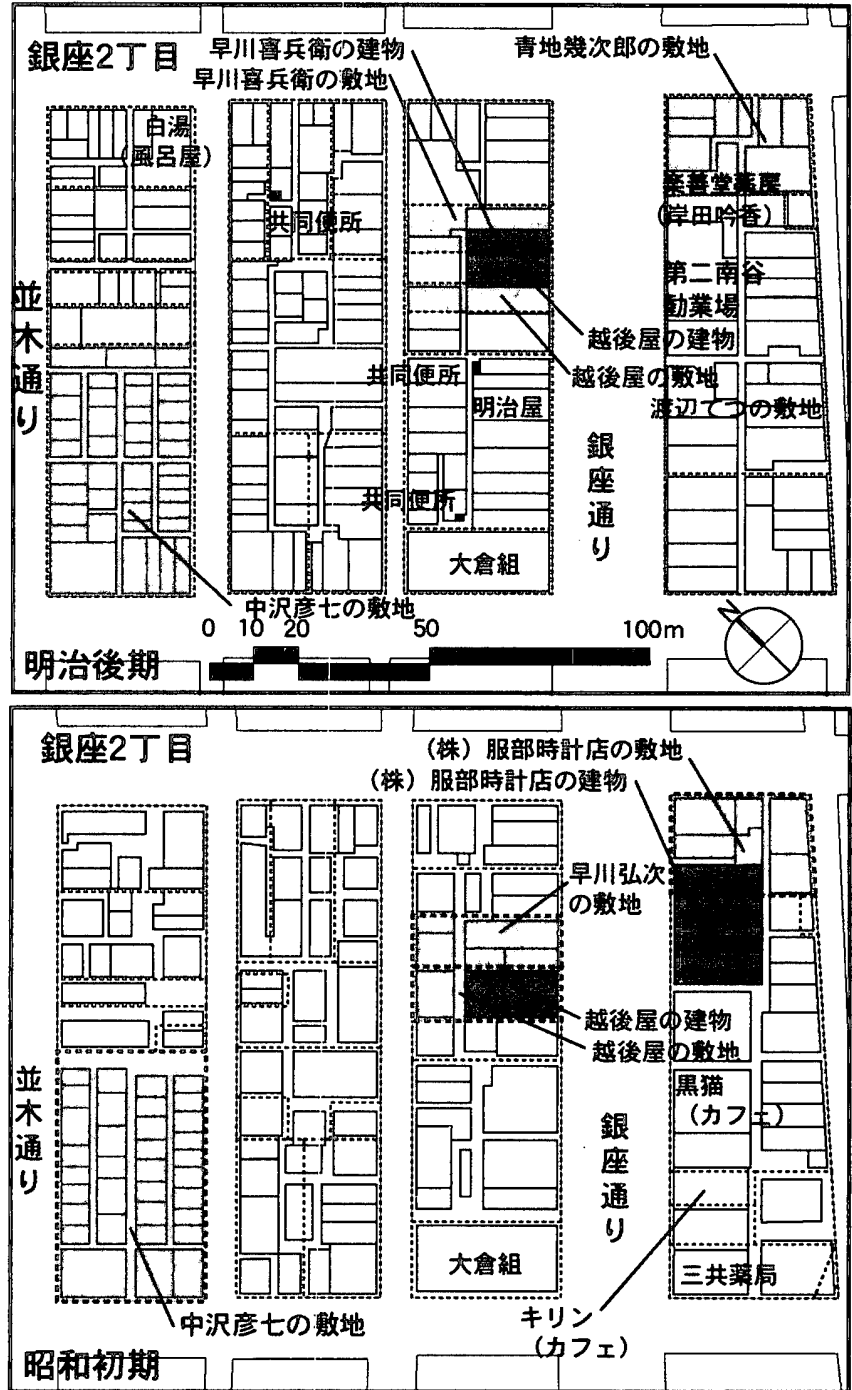

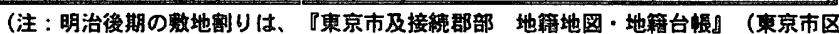
調桎会、1912 年)を参考に作成している。また建物の配置は、明治35年に作成された 『東京宗播区銀座附近户別一路图』(平田勇莫堂発行) をもとに作成した。

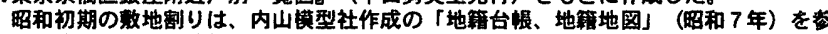
考に作成している。建物配固は、『火炎保険图』（昭和7〜11年）をもとに作成した。

次のケースとは異なり、明治後期同様に敷地内での大家と店子の関 係を保ち続ける。敨地内の空間構成も、敷地奥の建物配列に多少の 変化が見られるが、基本的に変わっていない。銀座にある 100 坪前 後の町屋敷型の敷地は、ここにあげた 2 つの例だけではなく、震災 後も空間構成を保ち続けるケースが多く見受けられる。

（2）大家と店子の関係を継承した300坪以上の広い潄地

このような町屋敷型以外にも、明治後期の空間構成を継承した敷 地がある。それは、借垉。借家経営を主目的とした不在地主と地元 の質商の敭地である（汇 8 ）。これらの教地は、町屋敖型と異なり、 間口、奥行とも長く、唼地面積も 300 坪以上と広いことが特徵であ る。以下 2 つの具体的な例を上げながら、影地内の空間構成がどの ように繼承されてきたのかを探ることにしたい。

一つは、銀座 2 丁目にある不在地主・中沢彦七の敨地である（図 2)。これは、628 坪に規模が大きい。この敷地には、借地・借家 用の店舗や住宅が建ち立び、内側の住宅にアプローチする路地が縦 横に巡らされている。不在地主が所有する敷地の空間構成は、一部 霞災後に分割売買され、細分化するケースもあるが、大半がまだこ 


\section{図3 土地と建物の関係比較図2（銀座1丁目）}

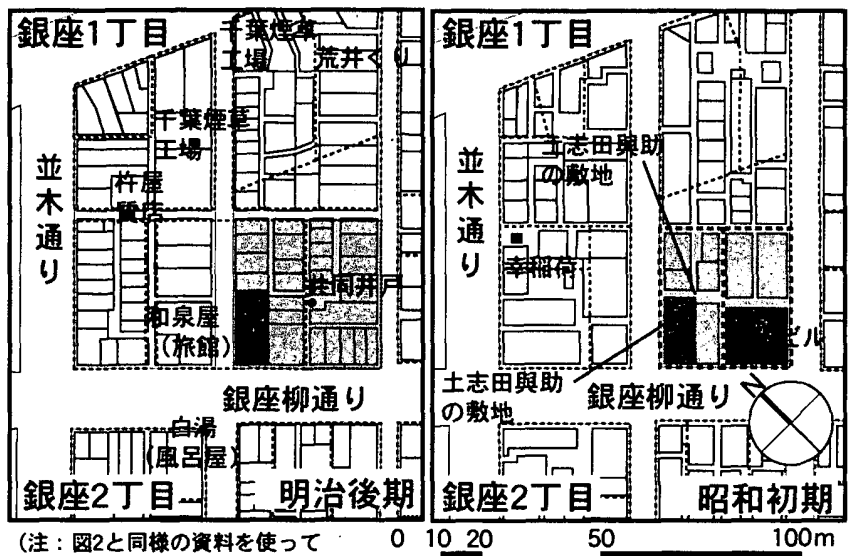

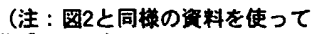
作成した。)

のような環境を維持し続ける（注 9）。しかも、このような敷地に は震災後近代建築が建つことがなかった。その大きな理由としては、 建物所有の権利が土地所有者と異なるケースが多く、一つの敷地で あるが、複雑な建物所有の関係をつくりだしていからである。土地 の売買だけであれば問題はないが、既存の建物の権利をまとめ、そ れらの建物をクリアランスして大規模なビルを建てることは、当時 大変難しかった。従って、土地を売買する時は、分割など、土地の 形状を変化させることが少ない。

2 つ目の三十間堀川治いにある銀座 5 丁目の例は、震災以前から 質商 (屋号・江島屋)を営む田村藤兵衛の敷地である（注10）。彼は、 震災後銀座の大規模土地所有者が次々に不在地主となるなかで、銀 座に所在地を置く数少ない人物である。彼の店は個人から法人経営 に移るが、土地の所有・管理は依然として個人で行っていた。また 震災を経た後も、敷地内では大家と店子の濃密な関係が空間として 再現される。 548 坪と広いこの敷地には、自らの店舗併用の大きな 屋敷が中央に構え、その周辺を借地・借家である一戸建ての建物や 長屋が取り巻くように建つ（図 4）。路地もそれらの建物を縫うよ うにしてイレギュラーに通されており、南北と東西の路地で構成さ れる銀座特有の路地構成ではない（注11）。この敷地は、先に見た 中沢彦七のケース、及び町屋敷型の敷地である土志田興助のケース と、立地場所と江戸時代の土地利用面に関して大きな違いがある。 それは、明暦の大火（1657年）後に町屋敷型の土地が再整備された 後、三十間堀川沿い周辺は物流関連の土地利用に変化したことで、 町屋敷型と異なる敷地の空間構成となった（注12）。同様のケース は他にも同じ三十間堀川治いで見ることができる。

以上具体的に見てきた 4 つの例は、いずれも震災を経ても敷地の 形態や規模に変化が起こらなかった例である。また、これらの敷地 は霞災以前から継承し続けている所有者が大半を締めていた。新し い建物が建つことで景観を大きく変化させるなか、安定的な土地の の維持、大家と店子の関倸の継続は、敷地内の空間構成の変化を最 小限に押さえることにつながったと言える（注13）。

\section{3.近代建策が建つ数地の変化パターン}

銀座には、震災後の 10 年間で約 130 棟もの鉄筋コンクリート造を 主体とした近代建築が建つ。このような大規模建築を建てる時は、 明治後期の敷地と建物と路地とで構成されていた空間の関係を変化 させる必要があった。それら一つ一つの変化を調べると、7つの変

\section{図4 土地と建物の関係比較図3（銀座2丁目）}
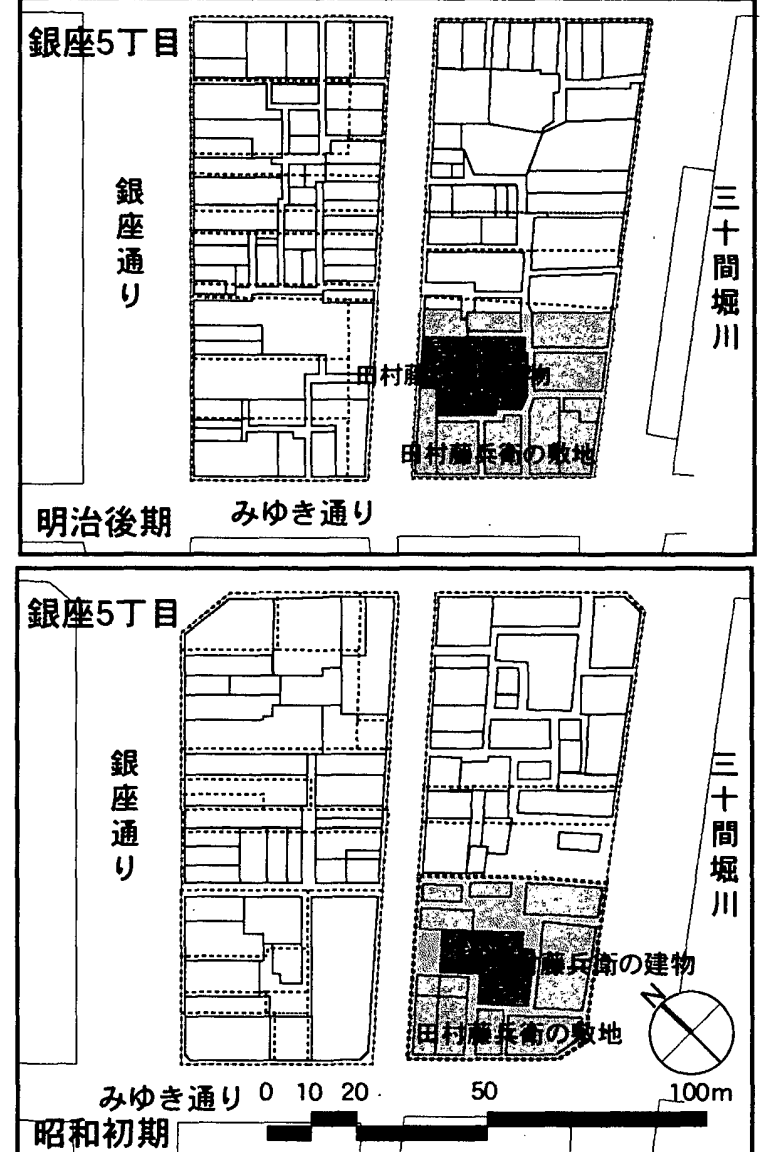

（注：图2と同倳の瓷料を使って作成した。ただし、銀座5丁目の田村臀兵衙 の建物は『京楧区銀座五六丁目銀座西五六丁目町内图』(昭和16年7月哞行) を考に修正を加えた。)

化パターンが読み取れる（図 5)。また、敷地割りの変化状況から、 大きく 3 つにグループ分けすることができる。それは、「変化がな かった敷地」、「統合された敷地」、「複数のままの敷地」である。 以下、近代建築が建てられた敷地の変化について分析する。

\section{（1）変化がなかった敷地の場合}

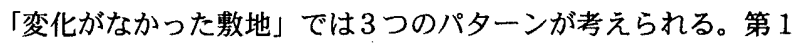
のパターンは、敷地規模を変化させず、複数の建物の一部を近代建 築に建て替えたケースである。銀座 1丁目の自社の敷地に建てた皆 川ビルがそれにあたる（図 3）。明治後期の敷地内の構成は、先に 見た隣地の土志田與助と同様町屋敷型である。このビルは規模がそ れほど大きくないために、裏通り側に長屋形式の店舗が並び、敷地 の内側には長屋も建てられている。ここでは、近代建築が建つが、 明治後期の空間構成を大きく変化させておらず、その規模によって 従来の敷地環境が維持し続けることを示している。

第 2 パターンは、第 1 と同様敷地の形態に変化がないが、その後 敷地いつぱいに近代建築が建つケースである。これは、銀座 6 丁目 の交詢社通り（横丁）治いにある瀧山町ビル（昭和 3 年竣工）がそ れにあたる（図6）。明治後期、通りに沿って連屋化した煉瓦建築 が並んでいたものをビル化している（注14）。この敷地は横丁側の 間口が長く、奥行が短い。それは、江戸時代通りに面して割られて いた敷地が、煉瓦建設の時横丁側に連屋建筑を建てることによって、 通り側であった敷地の正面性と空間構成を大きく変化させていたか 
図5 敷地と建物の関係変化のパ夕ーン図

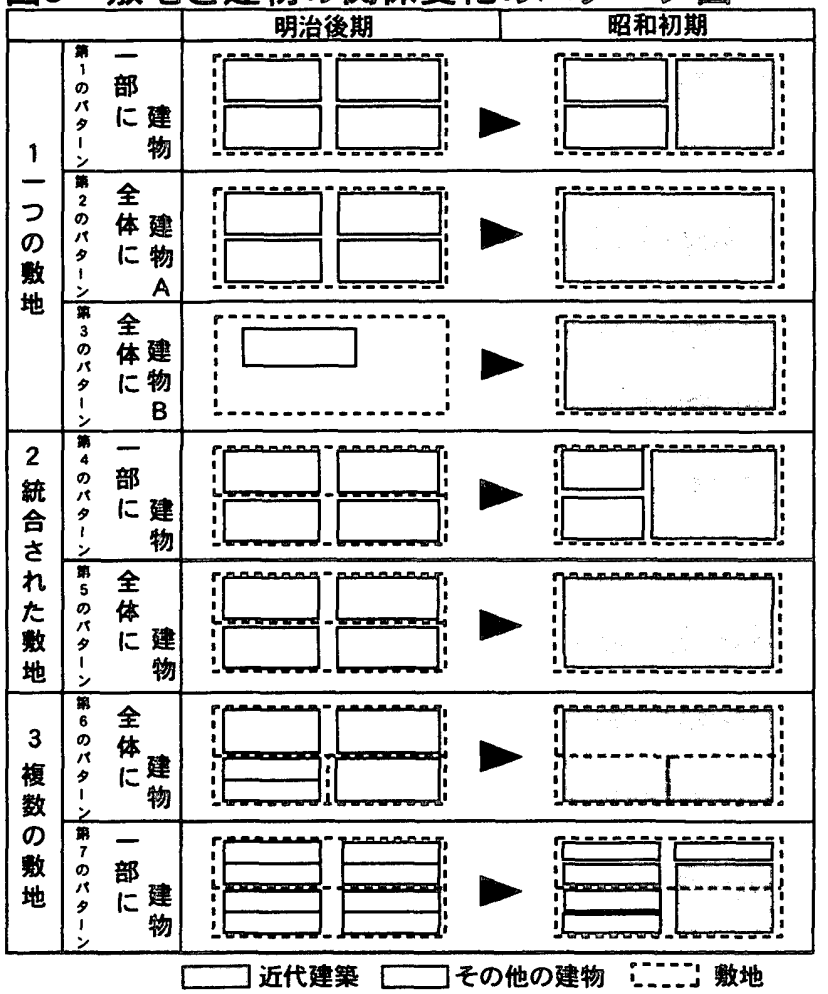

らである。そのめに、このような敷地では、本来奧にある居住者用 の建物に配慮することなく、近代建築を建てることができた。この ケースは、ブロックの角地に見られ、中規模な近代建築が建つ可能 性がある。

第 3 のパターンは、商店や長屋ではなく、個人が所有していた広 い屋敷である。すなわち、土地も建物も同一の所有者の土地に近代 建築が建つケースである。この典型例としては、銀座 3 丁目の外堀 通り沿い角地にある高木兼寛の屋敷をあげることができる（注 15）。 348 坪のこの敷地には、読売新聞社の社屋（昭和 14 年竣工）が建 つ（図 8)。ただ震災以前の中規模以上の敷地では、一般的に複数 の建物が建てられているので、このように土地と建物の所有者が一 致したビル化しやすい敷地条件は稀であった。

\section{（2）統合された数地の場合}

第 4、第 5 のパターンは、これまでにあげた 3 つの例とは異なり、 複数の敷地を統合して一つの敷地にし、近代建築を建てた例である。 まず第 4 としてあげるパターンは、以前分割していた町屋敷型の敷 地を再統合したものである。このような敷地は銀座通り沿いに多い。 統合以前の敷地の形状では間口が狭く、短冊状に細長い敷地である から、規模の大きな建物を建てることは難しい。そのために、土地 を統合し、100 坪前後の規模にした上で、近代建築が建てられた。 具体的には、銀座 2 丁目の銀座通り沿いにある越後屋ビル (昭和 15 年竣工）がそれにあたる（図 2）。このビルも、第1のパターン同 様に敷地一杯に建てていない。敷地内には路地が残され、裏通り側 に従来の小規模な商業建築が残る。これは、角地ではなく、通りに 面したブロックの中程にある 100 坪前後の町屋敷規模の敷地に近代 建築が建つ典型的な例である。

この第 4 のケースのように敷地全体に近代建築を建てていないケ 一スが、300 坪以上の敷地でも見るこができる。それは銀座 7 丁目
図6 土地と建物の関係比較図4（銀座7、8丁目）
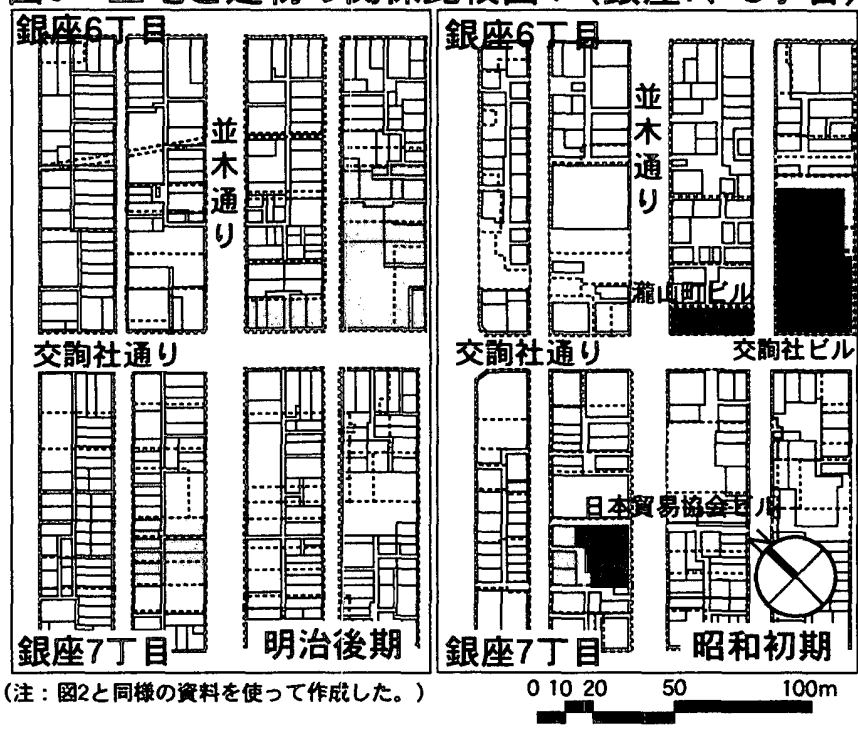

の日本貿易協会のビルである（図 6）。この敷地は所有者の異なる 3つの敷地が一つにまとめられたものである。ビルが建つ場所は並 木通り側の3分の 2 敷地である。残りは従来型の店舗が裏通り側に 軒を連ねている。ここは、町屋敷型の敷地を統合したものであり、 既存の建物所有者が残る状態でビル化したと考えられる。敷地が統 合できても、全体の空間を自由に使うことのできないケースが生ま れる。銀座では、規模の大小を問わず、このような条件の敷地が多 く、大規模な近代建築をどこにでも建てられる状況ではなかった。

第 5 のパターンは、日本貿易協会のビルが建つ敷地と同様に、敷 地規模が 300 坪以上と大きい。ただ、ここには大規模な近代建築を 1 つだけ建てることができた。この例は銀座 3 丁目の銀座通り治い にある銀座ビルデング（大正14年）とその敷地である（図 7）。 この土地の所有者となる第一徵兵保険（株）は、村越庄左衛門と松 沢八右衛門の敷地を購入し、786 坪の敷地に㹡大した。明治後期は、 これらの敷地を跨ぐようにして岩谷松平の広い面積を誇る店舗があ つた。すなわち、敷地とともに建物の権利関係が複雑化していない ことで、大規模な建築を教地いっぱいに建てることが可能になった のである。

この敷地以外にも、土地を集約化し、大規模な近代建築を建てた 例が見られる。それは、外堀通り沿いの銀座 1 丁目にある增田義一 の敷地である。このケースは、瞵の袮の敷地を合わせ、ブロック 内を一つの敷地にまとめ。敷地いつぱいに実業之日本社社屋（大正 13年竣工）を建てた（図 8）。このように、ブロックを占有した敷 地には大規模な近代建築泫建ちやすい。ただ、銀座ではこのような 条件を備えている敷地は泿座 8 丁目の京橋電話局など極めて少ない。 （3）複数のままの數地の場合

ここまで見てきた近代建築は、最終的に一つの敷地の上に建つこ とになる。一方、昭和初期には複数の敷地にまたがって大規模なビ ルが建つケースがある。このよな場合、2つのパターンが考えられ る。これらを第6、第7として見ていくことにする。第6のパターン では、複数の敷地が分割・統合による変化をせず、それらの上に近 代建築が建つケースである。これは、銀座 $6 丁$ 丁目にある交詢社通り 治いの交詢社ビル（昭和 4年竣工）がそれにあたる（図 6）。敷地 は 3 分割されており、2つの敷地を（財）交詢社か、残りの敷地を 


\section{図7 土地と建物の関係比較図5（銀座3丁目）}
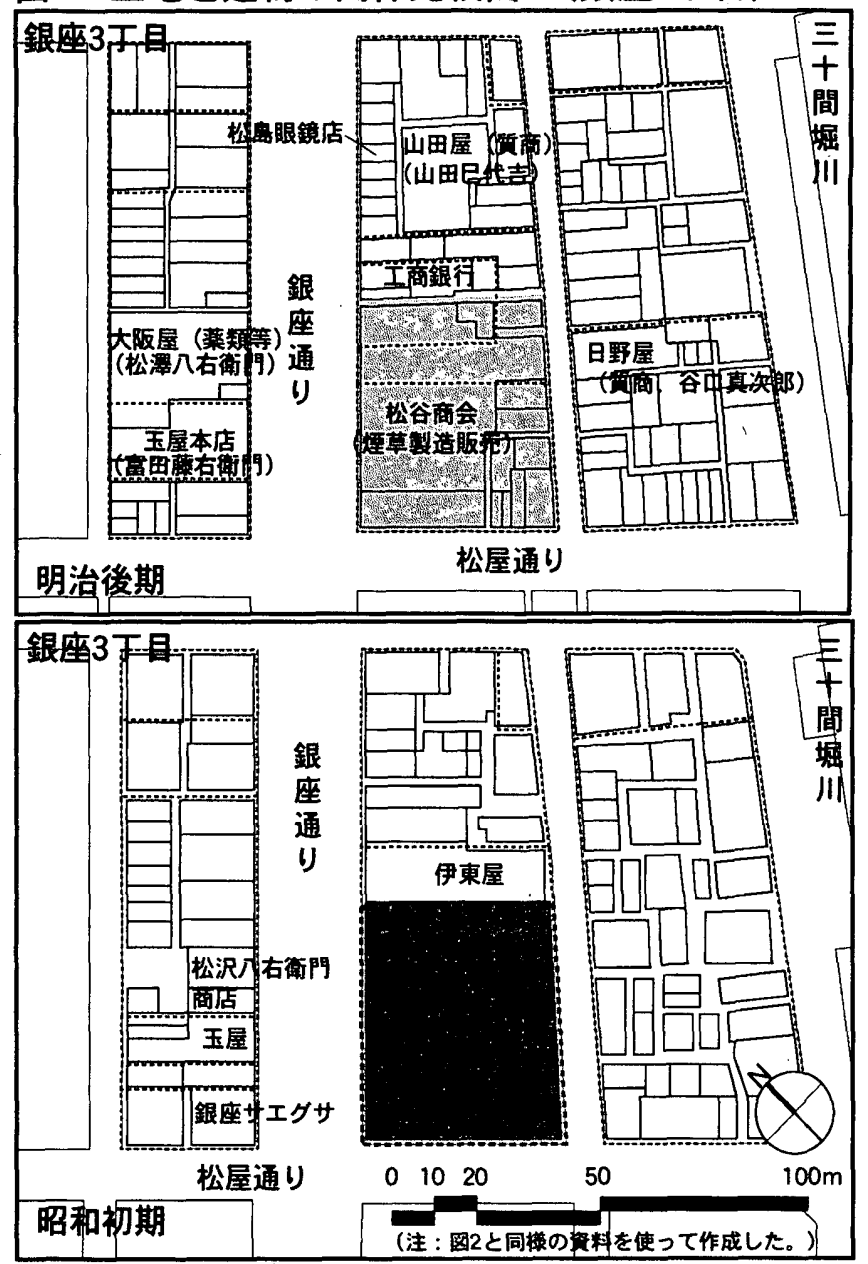

（株）三井銀行が所有していた。この状況は明治後期から戦後しば らくまで変化しておらず、そのまま維持され続ける。

最後の第7のパターンは、2つの敷地にまたがるように近代建築が 建つケースである。それは、銀座 2 丁目にある（株）服部時計店の 土地と建物である。ここには、老朽化した初代のビルを取り壊し、 同じ銀座4丁目角に2代目の本社社屋を建てるまでの仮の本社ビルが 建つことになる。この建物は、奇妙にも敷地とずれた所に建てられ る（図2）。まず土地の方は、青地幾次郎が所有していた 263 坪を 手に入北る。しかし、そこには煉瓦建築を所有する商人たちが何人 も存在していた。彼らはそこですでに商いをしているので、簡単に は敷地内の全ての建物権利を手に入れることができない。敷地内で 服部時計店が手に入れた建物は、南側の 1 店舗と、2つの敷地を跨 ぐように建つ岸田吟香の建物だけである。後は、彼が所有していた 店の残りと南谷勧業場の建物を買い取る。ただし、これらの建物が 建つ土地は渡辺てつが所有しており、土地と建物の所有が異なって いた（注16）。その結果、（株）服部時計店の仮本店ビルは自社が 所有する土地とズレた場所にできたのである。銀座では、土地と建 物の所有関係が別々のケースが多いために、大規模なビルを建てよ うとすると、このようなケースが生まれる。

\section{4.関東大霞炎後の近代建筑の立地特性之路地棈造の变容}

次に、以上のように建てられてきた近代建築が、銀座全体の都市 空間構造にどのような影響を与えたのかについて考察しておきたい。
図8 昭和初期の近代建築と路地の関係図

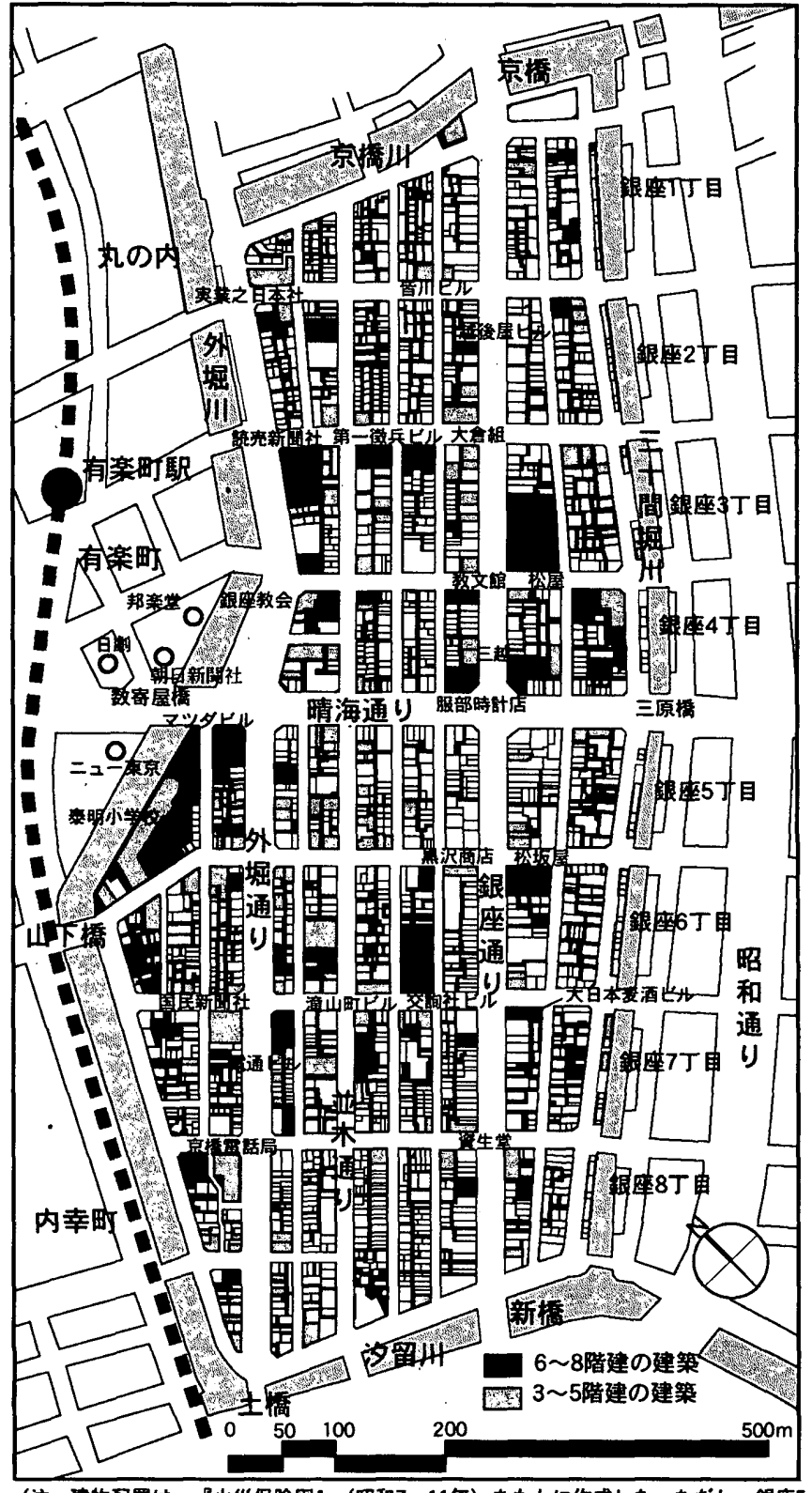

（注：建物配置は、『火炎保险図』（昭和7〜11年）をもとに作成した。ただし、銀座5

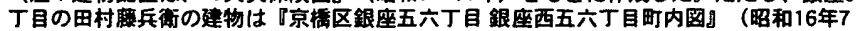
月唊行〉を参考に修正を加えた。)

ここでは、近代建築が立地する場所の特性と路地構成の変化に着目 する（図8）。

3.においては近代建築と敷地との関係を明らかにしたが、このよ うな建築が立地する場所にも幾つかのパターンが見られる。大きく は2つに分けられる。その一つは、通りと横丁の両側に面する角地 に立地するケースである。このような敷地に建てるメリットは、建 物の接道面が增え、プランニングの自由度が増えることである。た だ、それだけの理由でブロックの角地に近代建築が数多く立地した わけではない。それは、銀座の土地と建物の関係から選択された結 果でもある。3.において分析したように、複雑な敷地や建物の関係 を統合して近代建築が建つことはない。例えば、銀座通りと並木通 りの間のブロックを見ると、敷地が細かく分割され、小規模な建物 が密集している銀座1丁目や銀座8丁目の幾つかのブロックには、近 代建築が立地していない（図 8）。すなわち、銀座では分割されず 
に残された敫地で、借地・借家の建物による権利の複雑化していな い場所に近代建築が分布している。そのような委件を備えた所が角 地である。

これらの土地では、敨地内にある南北の平行型路地の一部が消失 する。例えば、銀座 4丁目の角地に三越百货店が建つことにより、 晴海通りまで抜けていた平行型路地が失われる。そこで、この路地 を補うように新しい建物に沿って直角型路地が設けられ、既存の平 行型路地が銀座通りと裹通りに抜けられるようにした。従来の都市 環境を維持するために、路地が柔軟に形を変えているのである。

いま一つは、ブロックの中程に近代建築が立地するパターンであ る。この場合は、近代建築の規模が小さくなればなるほど、従来の 都市槽造に対しての影智も少なくなり、立地場所に自由度が增す。 すなわち、旧来の敷地と建物と路地の関俰を大きく崩すことなく近 代建築を立地させることができる。3.において分析したパターンで は第 1 と第 5 そして第 7 がそれにあたる。銀座では、明治期におけ る教地の空間構成を大きく変化させずに近代建築が建つことで、ブ ロック内の生活の場が昭和初期においても維持される環境を確保す ることができていたのである。そのために、一万を越える人たちが、 銀座の土地に暮らすことができた。

\section{5.まと的}

以上分析してきたように、昭和初期の銀座は大きな災害があった にもかかわらず、都市構造は大きく变化することがなかった。その なかで、これらの仕組みを変えたのが近代建築である。しかし、大 規模な建物の立地は、それらが建つための敨地と建物の条件が整え られた場所に限定されていた。その点において銀座は、ある程度自 由な区画に近代建築を建てていった丸の内と大きな違いを見せる。 また、同じ江戸の町人地でありながら、震災後の帝都復興事業によ る土地区画整理で都市構造を大きく変貌させてしまった日本橋とも 異なる都市再生が図れた。近代建築の出現は、4.で考察したように 敷地内やその境界で路地構造の変化を生みだした。だか、このよう

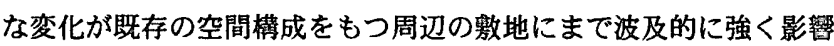
することはなかった。すなわち、新たな要素として近代建築が銀座 に建つことは、統一された都市景観の形成ではなく、歴史的な背景 に根ざした上での立地であったことになる。モダン都市と言われる 昭和初期の銀座は、変化しつつも、基本的に従来の都市の構造をし っかりと綎承していたのである。

(注)

1）ここで論じている銀座は、現在の銀座の筑囲を対象地域としていない。か つて四周を掘割で囲まれていた銀座搷瓦街が建設された筑囲である。

2）煩雑さを避けるために、文中及び図中の通り名は現在の名称を使っている。 また、町丁名についても現在の町丁名に統一した。

3）明治後期における土地の基礎資料は、『東京市及接続郡部 地籍地図・地 籍台㟪』（東京市区調冝会、1912年）を使った。また建物に関しては、明治35 年に作成された詳紐な住宅地図である『東京京橋区銀䧹附近戸別一覽図』（平 田勇美堂発行）を使っている。

昭和初期の土地所有に関しては、内山模型社が作成した「地籍台帳、地籍地

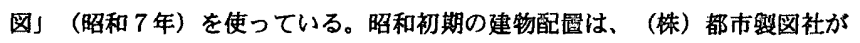
作成した『火災保険図』（昭和7〜11年）を使った。
4）関東大霞災以降、東京の下町では帝都復興事業による大埧かりな土地区画 整理が行われ、街区䱦成及び影地割りの境界を大きく变えた。

5）昭和 6 年の影地数は明治 45 年の477件から77件增加して554件となった。そ のなかで、300坪以上の大規視影地の件数は、ほとんど变化がなかった。それ に対して、120〜300坪の中規模の影地件数は隇少している。霞災を契機に、こ れらの規模を中心に敬地の分割が進み、40坪末満の小規模な数地数の增加した のである。一方、明治期に減少が澈しかった100〜120坪の數地をはじめ、60〜 120 坢の敭地は增加している。こちらは、小規模な敫地が再統合した結果であ る。

6）江戸初期の町人地は 60間街区が整然と並ぶように計画された。それらの街 区は通りから奥行20間の幅でブロックをつくり、その中を間口4〜間程度の幅

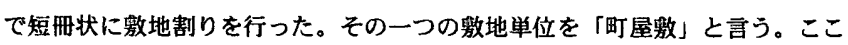
では、100〜120罣の標淮的な影地を「町屋影型」之呼ぶことにした。

江戸時代は、店と長屋で概成されるこのような町屋敂が一般的に大家と店子 の関係をつくりだしていた。

7）明治期は 40 啈以上の教地が 9 割近くを占めていた。一方、建物 1 棟の建筑 面櫝はほとんどが20啈に満たない。

8）戦前までは、銀座に質商汸数多く立地していた。彼らは規模の大きな數地 を所有するとともに、その土地で商いをしているケースがほとんどである。

9）戦後は、借地・借家のための大規模な數地の多くが細分化される。そのた めに、戦後の銀座には昭和初期に見られたこのような規模と土地利用の敂地が ほとんどなくなる。

10）銀座に複数の鹳地を所有する大規模地主の多くは、関東大赝災を契機に居 住地を郊外に移す。同時に、彼らは銀座のでの商いも辞め、不在地主となる。 11）明治後期の銀座の路地栱造は、「通りに平行に通された路地」(「平行型 路地」）と「通りに直角に通された路地」（「直角型路地」）の方向の異なる 2 つの路地が組み合わさることで独特の空間をつくりだしていた。（詳細な明 治35年の前揭地図から、このような銀座の路地構造の代組みが読み取れる。） 12）明曆の大火（1657年）以降、相割沿いは舟運による物流基地としての河岸 が整備された。その街区の内側は商籍や居住ではなく、物流産業の用途に土地 利用䎐換する。江戸時代の後期になると、このような町崖影の空間㯜成が変容 した敖地には、質商のような産業関連以外の立地が進む。そこでは、再び大家

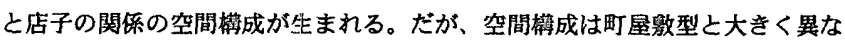
るものとなる。

13）昭和初期は、554件ある，敂地数のうち $45.3 \%$ (251件) の土地所有者が何ら かのかたちで明治後期の土地を継承し続けていた。枯瓦街建設後40年の藏月を 経た明治45年の割合が $16.1 \%$ (72件) であったことと比べると、その割合は檑 めて高い。しかも、これらは敨地の形状を変化させていないケースが大半を占 めていた。

14）䐈瓦街建設では、間口2〜 3間の店が数戸集まり一棟となる連䌇した媡瓦建 箱を建設している。この長屋のように各戸を連繶させ方法を「連屋化」と呼ぶ。

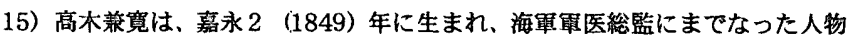
であり、東京慈恵会医院を創設する。彼はここを住居としていた。

16）搷瓦街建設の時、明治政府は土地に手をつけずに棟瓦建築だけを嬅䟽に建 て、それを払い下げた。その結果、明治期の土地所有と建物所有は異なるケー スがほとんどであった。

（2003年 4 月 4 日原稿受理， 2003 年 6 月 12 日採用決定） 